\title{
Inner/intercultural Dialog and Long-Range Ethics
}

\author{
KRZYSZTOF ABRISZEWSKI, TORUŃ
}

\section{1.}

The idea of intercultural dialog consists of several assumptions. One of them opposes dialog to other forms of intercultural contact like conflict and coercion. Dialog is a gentle way of filling up the intercultural gap. Conflict is a harder one. So there is a moral content in this assumption, it opposes negotiations to violence, and it says that to avoid violence, and thus to avoid suffering is the proper aim of the human actions. I call this assumption: "negotiations without suffering".

Another assumption of the idea of an intercultural dialog says something about the notion of culture. If it is an inter-cultural dialog, then we deal with, at least hypothetical, separated entities (or processes) called cultures. It says that the culture is a relatively homogenic and isolated whole, which can be studied and described as such. Although this may have been true in the seventeenth century, it seems out of date today. Contemporary cultures are so complex and multidimensionally linked to one another that in result - as Zygmunt Bauman writes- "everyone is a stranger today" (Bauman 1990, chapter 3). I call this assumption - accepting the doubts "heterogeneity of culture". It can also be called "multiculturalism".

The third part of my conceptual framework consists of some theses about the cultural function of philosophy. Richard Rorty in his Philosophy and the Mirror of Nature claims that philosophy should keep up cultural conversation (Rorty 1979, chapter 7). It is to be a sort of a keystone located between different cultural areas. Jean-Francois Lyotard in turn, puts forward a moral postulate in his theory of conflict and justice. He says that philosophers should fabricate vocabularies for those, who are unable to express their arguments and reasons in a situation of conflict. In the asymmetrical conflicts, the existing public vocabulary represents only one party while the other is knocked off to the abyss of silence. Thereby, a philosopher is obliged by the idea of justice to "give the voice" to the silent (Kwiek 1994, part 2). Finally, Józef Niżnik in his Arbitrariness of Philoso- 
phy defines philosophy by its function which is the ability to cohere the human symbolic world by arbitrary conceptual inventions (Niżnik 2006).

Having given those three conceptions, we can imagine philosophy as a practice that aims at linking and binding together separated cultural areas by operating on vocabularies, and thus by supporting negotiations and knowledge against violence. In short, the three approaches share the assumption of "negotiations without suffering" with the idea of the intercultural dialog.

Now, I would like to add the assumption of "heterogeneity of culture" to that view on philosophy. If it operates / should operate as a dialog stimulator and its "pillar", than it is dialog among different areas of heterogeneous cultures or among various strangers living in the same global society. The empirical differences among the areas are big enough to justifiably call them "cultures" (for the notion of culture see Banaszak, Kmita 1991).

Thus here are my claims about intercultural dialog. Since presently there is no way to hold the assumption of "homogeneity of culture", there is no way to interpret the notion of intercultural dialog in a narrow, purely ethnic sense. Contrary, intercultural dialog is a dialog among different areas of globalizing civilization. Furthermore, because of modernization processes, the civilization changes accelerate bearing fruit of "experiencing the loss of a life-world (Lebenswelt)", as Odo Marquard calls it (Marquard 1994, 43). This means that social reality changes so quickly that individuals permanently lose their competencies to cope in their everyday activities, because the very everyday reality reshapes continuously independently of their will and actions (Bauman 2000).

Thereby my next claim is: in such a permanently changing social and cultural reality there is no way to "settle" the dialog for good. In other words, it is impossible to resolve arising problems just by inventing a way of dialogizing and then ritualizing it (i. e. setting an institutional form). Contrary, changing reality permanently requires new tools, new vocabularies helping to keep the dialog up and to move it to new areas and new cultures. Dialog, according to claims of Rorty, Lyotard, and Niżnik, has to support the vitality of civilization by fabricating and preserving links among its different areas. It has to arise whenever there is a threat to negotiations without suffering and to justice, whenever a possibility of violence emerges on the horizon. Finally, it has to attempt to cohere cultural realities in order to enable us to make sense of the surrounding world and our lives. 
Philosophy has become more and more marginal throughout the twentieth century, so one can hardly imagine it as a political instrument for promoting dialog in the way of institutional changes. Thereby philosophy, viewed as a domain of operations on notions and vocabularies, remains at a cultural level and leaves the institutional level to other social forces. So it should recognize cultural gaps that threat negotiations without suffering, develop conceptual instruments for filling them, i. e. for describing the gap situation, and expressing the needs and desires of the individuals involved. And finally it should develop a general vision that allows temporarily cohering the culture.

Inspired by the works of Zygmunt Bauman, Bruno Latour, and Hans Jonas, I call this project "long-range ethics". Bauman remarked that moral impulse is weak and unable to travel further beyond our life-world (Bauman, Tester 2003, 165). Jonas noticed the necessity of working out the ethics that would be able to overcome this obstacle (Jonas 1980). Latour together with other Actor-Network Theorists has given us instruments to investigate and describe long-range actions (Latour 1987, 177-257).

Thus the long-range ethics project could be described as follows: Our moral experiences, and ethics, that is the many ways we put the experiences into words (theories, proverbs, narratives, etc.) are locked in the cocoon of the life-world (Lebenswelt). So is our moral sensitivity. So is also our ability to recognize and interpret what is going around. One may try to explain this situation of humans being tied to a life-world perspective referring to biology or history. It could be said that humans have evolved as primarily belonging to small communities. It could also be said that throughout the whole history, social reality relied on small groups. Only the modernization processes change, or even destroy this arrangement. Small communities, based on face-to-face relations, start to weaken and disappear, replaced by big social organizations based on abstract contacts. In other words, the blur and complex world of institutions remaining beyond the horizon of our life-worlds grows bigger and bigger.

Earlier, the individual actions usually were followed by the effects that were easy to observe and grasp in a moral perspective. Modernization has changed that, inscribing most of (all?) everyday individual actions in the wider institutional contexts. The direct effect of this is that the results of human actions occur far away in time and space from their sources. The easiest way to imagine that is to think about a war or ecology. On the one hand, we have a direct fight with swords or sticks, when an individual faces his/her enemy. On the other hand, we have a soldier firing a bomb in 
a situation resembling a computer game: there is a screen, a joystick, and a comfortable armchair, but there is no physical enemy. Only the electronic trace of an enemy. In the same way, we can see the relation between radioactive garbage of today left as a problem for tomorrow's generations. It is easy to multiply the examples, but it is crucial not to stick only to those two contexts. Contrary, moral understanding of the areas possessed by the networks of techno-science, economic markets, and politics is a vivid problem. In the same way, we do not understand morally our individual, everyday actions that originate in our life-worlds, but result far away from them.

In accordance with the project of long-range ethics that would keep up intercultural dialog, I would like point out briefly the areas of possible break downs and gaps in social and cultural reality. I will use various theories of modernization for that purpose. In other words, I would like to point out the areas that enable a dialog to get started, to be kept up, or to be intensified. Certainly, this list is not complete. However, facing the acceleration of civilization changes does increase the doubts about the very possibility of a complete list.

\subsection{Slow and fast}

The slow time - fast time gap results in two groups of problems: domination of fast time and information excess (Eriksen 2001). Slow time is characterized by linearity and cumulativeness. Slow linear time leads to the idea of progress, personal development, continuity of individual and social projects, long-term planning.

Fast time accelerates some of the features of slow time, so the continuous line turns into a set of separated dots of intensity. Cumulative line turns into cumulated points. In fast time, projects are short-term, because reality changes too quickly to keep them too long. Development of coherent personality is replaced by the juggling of identities. Continuity and coherence of projects retreat for contingency, ad hoc actions, manipulating with anything at hand. Thomas Eriksen calls it "the Lego syndrome" - anything is connectable to anything else (Eriksen 2001, chapter 7). He also claims that fast time is contagious and tends to displace slow time. This means that slow time groups and individuals move towards social margins. 


\subsection{Writing and electricity}

Some literature studies result in mass education, in which individuals socialized in McLuhan's "Marconi constellation" meet requirements created by the culture of writing. Individuals used to rhythm of television and the Internet interactivity are confronted with individualizing writing. Their inclination to search for links and to do many different things simultaneously proves to be an obstacle because knowledge consists in classifications and they are demanded to show bodiless, one-channel attention (de Kerkhove 2001, McLuhan 2003). Students handle this in different ways: by diagnosed dyslexia and dysgraphy, watch films instead of reading books, suffer of ADHD cured pharmacologically, by double adaptation.

I view all those phenomena as results of cultural gaps, which need the intercultural dialog. It would link fast time culture with the slow time one, information excess culture with information deflation culture, culture of writing with culture of electric media. Lack of good vocabularies for describing the gaps make the intercultural contacts result in disease, oddity, others' "ill will", or conflict.

\subsection{Risk and partial modernization}

Ulrich Beck in his Risiko Gesellschaft claims that modernization fabricated the new forms of risk (Beck 1986). I start with the social risk.

He claims that modern individualization was only partial, and is now completed (Beck 1986, part 2). Processes of individualization have destroyed traditional protections spread above the individuals, like social class or stratum and left the nuclear family as the last protection. However, mass education together with other processes let us notice inherent modern injustice consisting in inscribing men in the labour market and women in not paid home work. The latter was in fact a invisible fundament of modernization. I think we need not only institutional solutions for that injustice, but we also need a vocabulary to comprehend, to describe, and to discuss and evaluate it; a vocabulary which would be able to express the experiences of the "internally" colonized.

The clash between network individualism and traditional community bond is the other consequence of individualization (see Castells 2000 on network society). The first is based on weak ties, and "wallets" of personal lives, the latter on strong bonds and strong identification mechanisms. 


\subsection{Technoscience: the changing and the changed}

"Natural" risks are tied to unpredicted consequences of modernity. Nature is not "out there" any more, it is an integral part of the collective. Instead of nature, we should speak of surprisingly associated hybrids possessing social, natural, and discursive features. The associations may fabricate risk.

Thus, two general claims: 1. Technoscience, while stimulating modernization, also stimulated unpredicted consequences that may turn into risks (Beck 1986, part 1). 2. Technoscience in the modern world fabricated the new beings - hybrids, which have populated our collective through the "back entrance" and unpredictably reshaped it (Latour 1993, Latour 2004).

Thereby my thesis is: presently, we need an intense dialog between those who participate in fabricating hybrids, and the "receivers". In other words: dialog between the "inside" of technoscience and its "outside". We need to start it with deconstructing the scientistic ideology which has protected the way technoscience operates.

\section{Short-range and long-range ethics}

Having given various theories of modernization, we can throw light on various areas that require dialog. It needs to go on among groups, individuals, different parts of one's life and mind, institutions, and so forth. I spoke of "intercultural dialog" or "long-range ethics" to name that multiform need.

The notion of long-range ethics stresses in turn on different attributes of our life: on the fact that our routine actions in our life-world cause results far beyond it, and vice versa, the effects we observe in our life-worlds are caused by something or someone located far beyond it. I think, Jonas is right, when he claims that this is quite a new situation in our history (Jonas 1980). Thus, for purely pragmatic reasons - in order to survive and live as happily as we are able to - we philosophers should contribute to fabricating the instruments that would help to cope in such a strange world.

Besides that inside philosophy, a dialog between short-range and longrange ethics should be started. The aim is to merge them together, and not to replace one with the other one. And there should be started a dialog in the culture between fast time areas and slow time areas; between those who happen to be on the bright side of modernization, and those who remain on the unseen, dark side; between those, who, like philosophy professors, feel in the culture of writing like a fish in a pond, and those, who are drowned 
in the electricity culture, and feel like strangers in the Gutenberg galaxy; between those, who are afraid of community mechanisms, but have learnt to live in the society of network individualism, and those, who do not grasp the latter, but view it as a disintegration of tradition and society; between those who support social change by stimulating operations of science, and those, who take these changes as something happening without their will and participation. In the last case, the dialog should reshape traditional scientism, and open the way for a discussion about the collective by simultaneously using political and scientific resources. Ulrich Beck talks of a transition from traditionally specialized science to the science specialized in connections (Beck 1986, chapter 7).

Obviously, all those areas require dialog as much as institutional actions, which philosophers, as a professional group, can hardly influence. But we do have influence on creation of new notions, on their connections, and on viewing our world in a new perspective - cognitive, ethical, social or political. This is exactly what I would expect from involving philosophers in the inner/intercultural dialog.

\section{REFERENCES}

Banaszak, G., Kmita, J. 1991 Spoleczno-regulacyjna koncepcja kultury, Warszawa: Instytut Kultury.

Bauman, Z. 1990 Thinking Sociologically, Oxford: Blackwell.

- 2000 Liquid Modernity, Cambridge: Polity Press; Malden Ma: Blackwell Publishers.

Bauman, Z., Tester, K. 2003 O pożytkach z watpliwości. Rozmowy z Zygmuntem Baumanem, translated by Ewa Karasińska, Warszawa: Wydawnictwo Sic!.

Beck, U. 1986 Risikogesellschaft. Auf dem Weg in eine andere Moderne, Frankfurt am Main: Suhrkamp Verlag.

Castells, M. 2000 The Rise of the Network Society, Oxford: Blackwell.

De Kerckhove, D. 2001 Powtoka kultury. Odkrywanie nowej elektronicznej rzeczywistości, translated by Witold Sikorski i Piotr Nowakowski, Warszawa: MIKOM.

Eriksen, T.H. 2001 Tyranny of the Moment. Fast and Slow Time in the Information Age, London: Pluto Books.

Jonas, H. 1980 Das Prinzip Verantwortung, Frankfurt am Main: Insel Verlag.

Kwiek, M. 1994 Rorty i Lyotard. W labiryntach postmoderny, Poznań: Wydawnictwo Naukowe IF UAM.

Latour, B. 1987 Science in Action. How to Follow Scientists and Engineers through Society, Cambridge Mass.: Harvard University Press. 
- 1993 We Have Never Been Modern, translated by Catherine Porter, Simon \& Schuster, New York, London: Harvester Wheatsheaf/Prentice Hall.

- 2004 Politics of Nature. How to Bring the Sciences into Democracy, Cambridge, London: Harvard University Press.

Marquard, O. 1994 Rozstanie z filozofiq pierwszych zasad, thum. Krystyna Krzemieniowa, Warszawa: Oficyna Naukowa.

McLuhan, M. 2003 Understanding Media: The Extensions of Man, Gingko Press.

Niżnik, J. 2006 The Arbitrariness of Philosophy, The Davies Group Publishers.

Rorty, R. 1979 Philosophy and the Mirror of Nature, Princeton, NJ: Princeton University Press. 